\title{
CHARACTERISTICS OF POLISH INTERNATIONAL FREIGHT TRANSPORT
}

\begin{abstract}
The aim of the article was to present data on the condition of the Polish sector of international freight transport, including transport potential, transport performance according to types of transport and its share in the European market, as well as the results of ITS cost studies. The results of the average cost of 1 vehicle kilometers traveled of milage and unitary costs in the years 2009-2016 were analyzed in the surveyed companies performing transport mainly on the EU market.

Keywords: transport heavy goods vehicles, costs
\end{abstract}

\section{Introduction}

The freight transport market in Poland is a market with great development opportunities and at the same time functioning in conditions of increasingly more intense domestic and international competition. In the case of international transport, the fact that the governments of various EU countries take attempts to protect them against their own carriers is additionally worrying. Also, the EC's plans (mobility package) aimed at unifying the economic and social conditions of transport companies on the EU market will increase the cost of the activities of Polish enterprises of international freight transport, and thus the possible loss of advantage in the competitive transport market.

It is important for authorities responsible for the Polish transport policy to have up-to-date data on the situation on the transport market and change trends. The task of advisory entities for the Ministry of Transport, such as the Motor Transport Institute is among others monitoring of selected areas of the car transport market, including the international transport market. One of the elements 
is the examination of the formation of average unit costs in international freight transport companies registered in Poland, including those operating on the EU market. Costs are a synthetic measure in which both external factors and internal factors affecting enterprises are reflected.

\section{Development of the potential and work of international freight transport}

Road transport in Poland in recent years and especially from the year of Poland's accession to the EU, thanks to the skills of its staff and its efforts and also due to lower costs of running business (including lower costs of employing drivers) in comparison with transport companies of the so-called "old" EU, strengthened its position as the leader of the EU transport market in international transport.

The main factors contributing to the dynamic development of international road transport companies in Poland in recent years were ${ }^{1}$ :

- liberal rules of access to the profession of a carrier and the transport market;

- the abolition of customs barriers within the EU;

- market globalization;

- an improving economic situation in Europe;

- geographical location of Poland;

- easy access to means of transport;

- lower costs of Polish carriers in comparison with the costs of Western carriers;

- the ability of the Polish carriers to acquire the market.

According to the International Transport Office of the General Inspectorate of Road Transport, international transport (as at the end of 2016) was performed approximately by 32100 companies registered in Poland ${ }^{2}$ (with valid licenses), which is less than three times as compared to the situation in December $2004^{3}$ (Figure 1).

The number of licenses issued by companies performing international transports as at the end of 2016 amounted to approximately 205400 and increased less than three and a half times compared to the corresponding number at the end of 2004 (Figure 2).

1 J. Waśkiewicz, Z. Kordel, I. Balke, P. Pawlak, Badania średnich jednostkowych kosztów w przedsiębiorstwach transportu ciężarowego za okres II pótrocza 2003 r. i I pótrocza 2014 r., ITS Papers No. 6403/ZBE, Warsaw, 30.04.2015.

2 By convention, in a simplified form, the further part of the article is also used to describe the term "Polish truck transport" referring to enterprises registered in Poland.

3 Drawing based on: K. Bentkowska-Senator, Z. Kordel, J. Waśkiewicz, Transport samochodowy ładunków, ITS Publisher, Warsaw 2009, p. 47; Report - Documents issued by GITD - valid in legal transactions, as at December 31, 2015, www.gitd.gov.pl (access: 22.02.2018). 


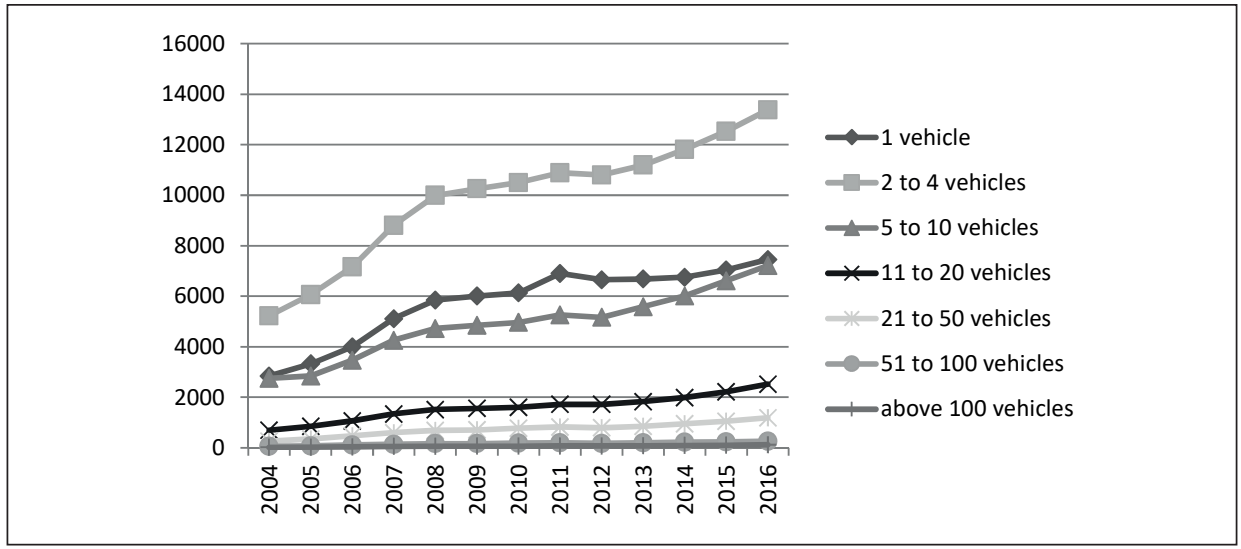

Figure 1. The number of international freight transport companies in Poland in the years 2004-2016 according to their size groups measured by the number of trucks [enterprises] Source: own elaboration based on: GITD data

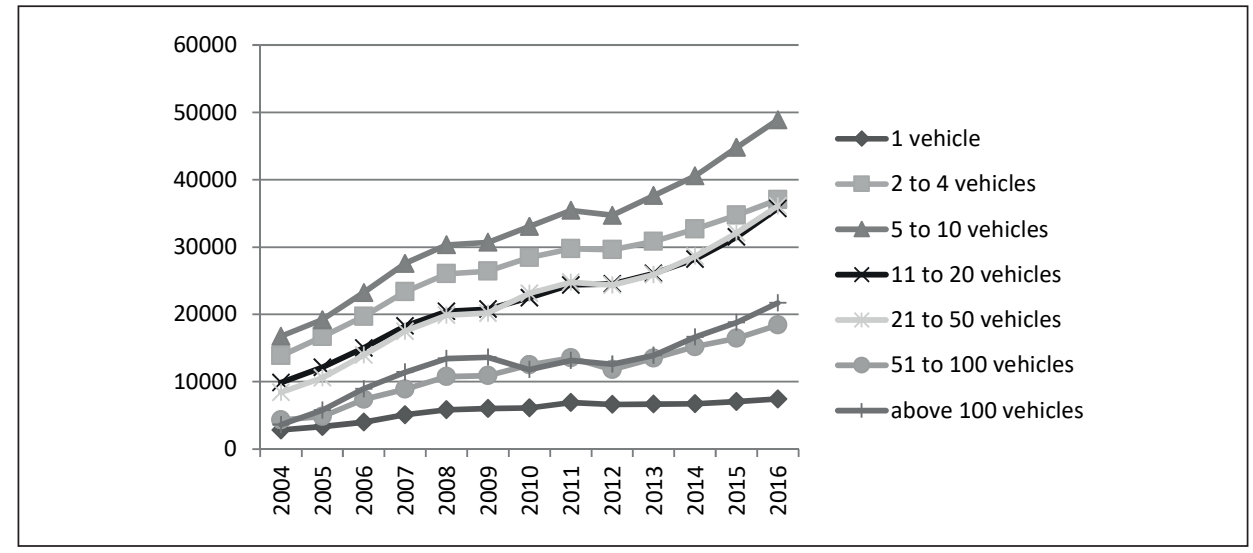

Figure 2. The number of trucks in international freight transport companies in Poland in the years 2004-2016 according to their size groups measured by the number of vehicles [vehicles]

Source: own elaboration based on: GITD data

In the years 2004-2016, the average number of trucks in the statistical enterprise of international transport of loads increased from 5 vehicles to 6.4.

The total transport carried out by Polish freight transport with maximum permissible weight (Dmc) exceeding 3.5 $\mathrm{Mg}^{4}$ in 2016 amounted to 1331.7 million tons, and transport work was 290.7 billion FTKs (an increase less than twice, and almost three times higher than in 2004). International transport amounted to 242.9 million tons in 2016, and transport work to 184.1 billion FTKs ${ }^{5}$ (an increase of nearly six times and more than four times higher than in 2004) (Figure 3).

4 Central Statistical Office - "Transport - results of operations" in 2014, Methodical notes, p. 25.

5 Central Statistical Office - "Transport - results of operations" in 2016, p. 169. 


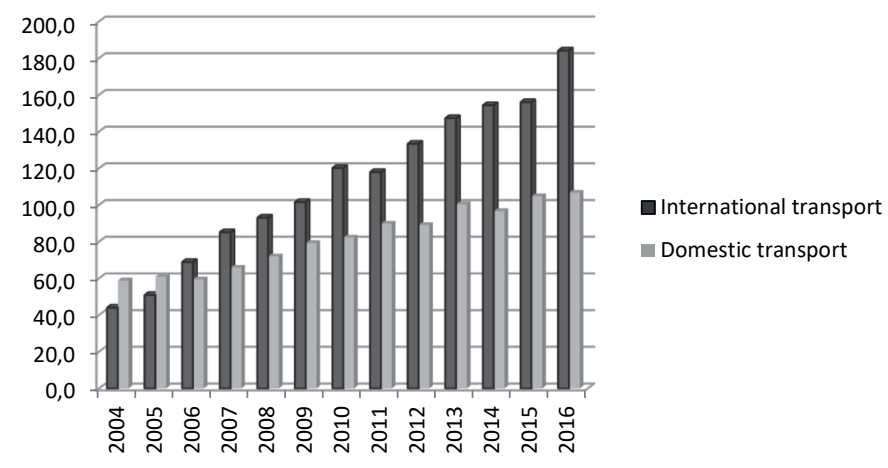

Figure 3. Transport performance of Polish freight transport made with vehicles over $3.5 \mathrm{Mg}$ dmc in the years 2005-2016 [billion FTKs]

Source: own elaboration based on: CSO data - "Transport - results of operations" for the years 2005-2016

Generally, in Polish freight transport, an increase in the average transport distance of 1 ton of cargo was observed, from around $140 \mathrm{~km} / \mathrm{t}$ to around $220 \mathrm{~km} / \mathrm{t}$. This statistically documented phenomenon was the result of a dynamic increase in the share of transport work in international freight transport in total from $42.3 \%$ in 2004 to $63.3 \%$ in 2016. The average distance of 1 ton of cargo in international transport in 2004 was about $1030 \mathrm{~km} / \mathrm{t}$, and in 2016 about $760 \mathrm{~km} / \mathrm{t}$, which, with the high growth rate of international transport performed by lorry transport, indicates that Polish carriers will take over shorter distances in the discussed years.

In addition, in the analyzed period, an increase in the average annual transport performance of a statistical truck operated in international transport was noticeable. In 2005, the average efficiency of transport performance amounted to around 701.000 FTKs/vehicle, and in 2016 about 896 thousand FTKs/vehicle (Figure 4).

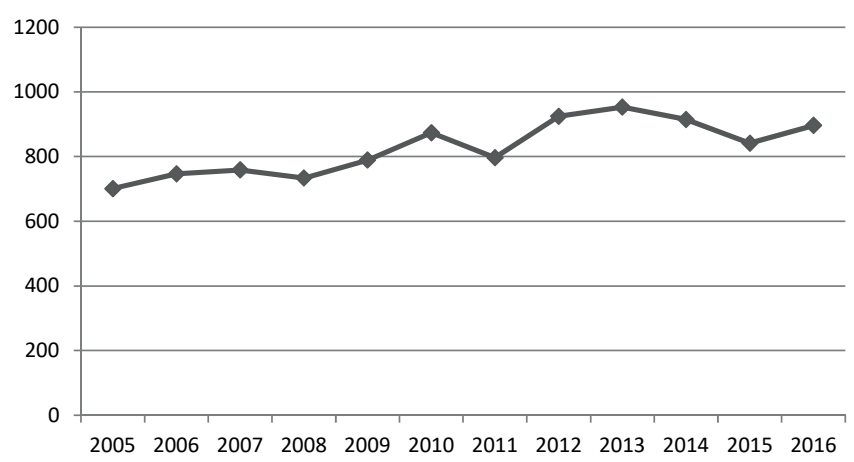

Figure 4. Average efficiency of transport performance of a statistical vehicle in Polish international transport in the years 2005-2016 [FTKs/vehicle]

Source: own elaboration based on: the data from the Central Statistical Office "Transport - results of operations" in the years 2005-2016 
Initially, the increase was mainly due to the dynamic development of demand for transport due to the development of international exchange of goods and the growing competitiveness of Polish carriers on the international transport market (cabotage transport and transport between third countries). Some decrease in the average annual transport performance of a statistical truck in the years 2013-2015 was influenced by the growing competition on the international road transport market caused by the strong expansion of carriers of countries such as Lithuania, Estonia and Slovakia. The competitiveness of road transport from these countries was influenced by on the decline in rates for transport services on the European market observed in recent years, including the reduction of Polish carriers' freight rates, resulting in a decrease in their profitability.

In the structure of types of cargo transport by international road transport from 2005 to 2016, the export and import of cargo mass to Poland increased over three times. In addition, transports carried out by Polish companies between foreign countries increased significantly (over seven times according to transported tons and five times in transport performance) and cabotage transport (less than 16 times in the mass of transported loads and 20 times in transport work) (Table 1).

Table 1. Transport and transport work of Polish international freight transport in 2005 and in 2016 by type of transport

\begin{tabular}{|l|r|r|r|r|r|r|}
\cline { 2 - 7 } \multicolumn{1}{c|}{} & \multicolumn{2}{c|}{2005} & \multicolumn{2}{c|}{2016} & \multicolumn{2}{c|}{$\begin{array}{c}\text { Dynamics } \\
(2005=100 \%)\end{array}$} \\
\cline { 2 - 7 } \multicolumn{1}{c|}{} & $(\mathrm{t})$ & $(\mathrm{mln} \mathrm{t})$ & $(\mathrm{t})$ & $(\mathrm{mln} \mathrm{t})$ & transport & $\begin{array}{c}\text { transport } \\
\text { work }\end{array}$ \\
\hline $\begin{array}{l}\text { Total international transport } \\
\text { including }\end{array}$ & 52551 & 50886 & 242858 & 184115 & 462.1 & 361.8 \\
\hline export & 21286 & 20570 & 72980 & 62206 & 342.9 & 302.4 \\
\hline import & 1953 & 19018 & 63573 & 55901 & 325.5 & 293.9 \\
\hline $\begin{array}{l}\text { Transports between foreign } \\
\text { countries }\end{array}$ & 9314 & 10645 & 68261 & 53037 & 732.9 & 498.2 \\
\hline transit through Poland & - & - & 3709 & 5831 & - & - \\
\hline cabotage & 2420 & 653 & 38044 & 12971 & 1572.1 & 1986.4 \\
\hline
\end{tabular}

Source: own elaboration based on: CSO data - "Transport - results of operations" for the years 2005-2016, p. 169

\section{Quality of the fleet in terms of emissions standards for exhaust gases}

The high competitiveness of Polish international carriers resulted not only from price competitiveness, but also from quality, which was exemplified by the development of a modern (according to the pollutant emission standards) park in the structure of used vehicles.

Vehicles complying with the Euro 5 and Euro 6 emission standards for exhaust gas pollution in 2016 accounted for $69.1 \%$ (in $201560.8 \%$ ) of the total park in these enterprises (Figure 5). 


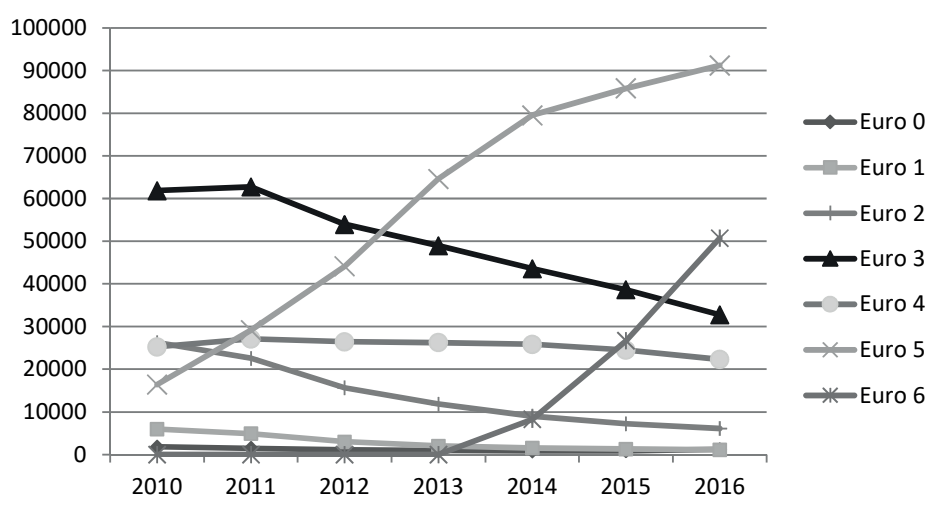

Figure 5. The number of heavy vehicles in international transport companies according to emission standards for exhaust gases in 2010-2016 in Poland [pcs]

Source: own elaboration based on GITD data: Report - Documents issued by GITD - valid in legal transactions, as at December 31, 2015, www.gitd.gov.pl (access: 22.02.2018)

It should be emphasized that among the registered in Poland companies of international freight transport, the share of trucks complying with the Euro 2 and earlier standards declined significantly.

\section{Transport of Polish international freight transport against the background of EU transport}

Polish international carriers definitely dominate in the transport work of the EU, international truck transport ${ }^{6}$ (Figure 6). In 2005-2015, this share increased from $8.2 \%$ to $25.1 \%$.

For example, in 2015 the share of German carriers in transport performance on the EU market amounted to $7.3 \%$ and French carriers accounted for around $2 \%$. This fact is the result of high competitiveness of Polish road carriers on the international market.

The development perspectives of tasks facing Polish freight transport are also positive. According to expert forecasts, a relatively significant increase in the transport performance of this transport is expected by 2030 compared to the transport work in 2016.

6 Central Statistical Office - "Transport - results of operations" in 2015, p. 284. 


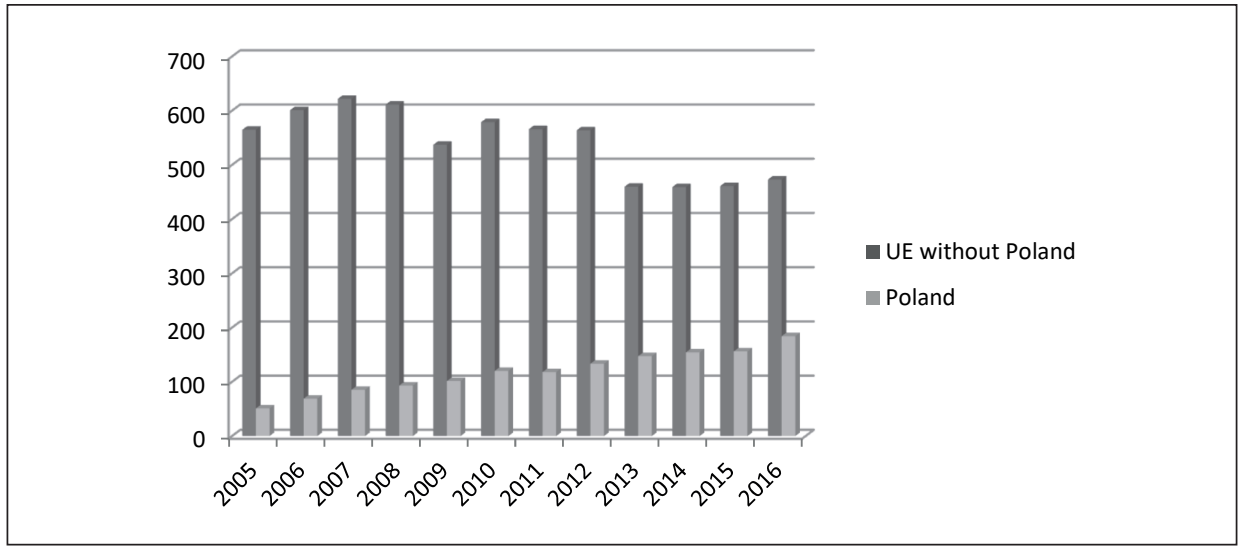

Figure 6. Transport work performed by Polish international freight transport against the background of international freight transport work in other EU countries in 2005-2015 [billion FTKs]

Source: own elaboration based on: CSO data - "Transport - results of operations" for the years 2005-2016

\section{Costs tests in international transport}

The competitive costs (compared to other carriers) of unit costs were determined by the market success of Polish international road carriers. Examined by ITS in cooperation with the ZMPD, the average cost of 1 mileage in the surveyed group of Polish enterprises with a dominant share of transport in relations with markets in other EU countries, universal rolling stock over $12.0 \mathrm{Mg}$ dmc, in 2016 amounted to PLN 3.85/vehicle kilometers traveled ${ }^{8}$ (Figure 7).

The dynamics of changes in average costs of 1 vehicle kilometers traveled of mileage in the field in question in 2009-2016 amounted to around 129\%. The increase in average costs and mileage in the analyzed period was mainly due to the increasing costs of fuels, an increase in driver salaries and an increase in the cost of using roads. Fuel costs increased by about 33\% during this period, road toll costs increased by over $120 \%$, and driver costs, drivers' delegations and employer's social insurance costs increased by 66\% (Table 2).

7 J. Waśkiewicz, Z. Kordel, S. Dorosiewicz et al., Projekcja rozwoju rynku międzynarodowego transportu ciężarowego w Polsce do 2030 r. Uwarunkowania, scenariusze i efekty, ITS Papers No. 06/17/ZBE/002 (in progress).

8 J. Waśkiewicz, Z. Kordel, E. Kamińska, P. Pawlak, Badanie stanu i kierunków zmian na rynku transportu samochodowego w Polsce, part 2, Badanie kosztów i stawek przewozowych w przedsiębiorstwach międzynarodowego transportu ciężarowego w 2016 r. i analiza zmian w okresie 2009-2016, ITS Papers No. 6600/2/ZBE, Warsaw, 30.06.2017. 


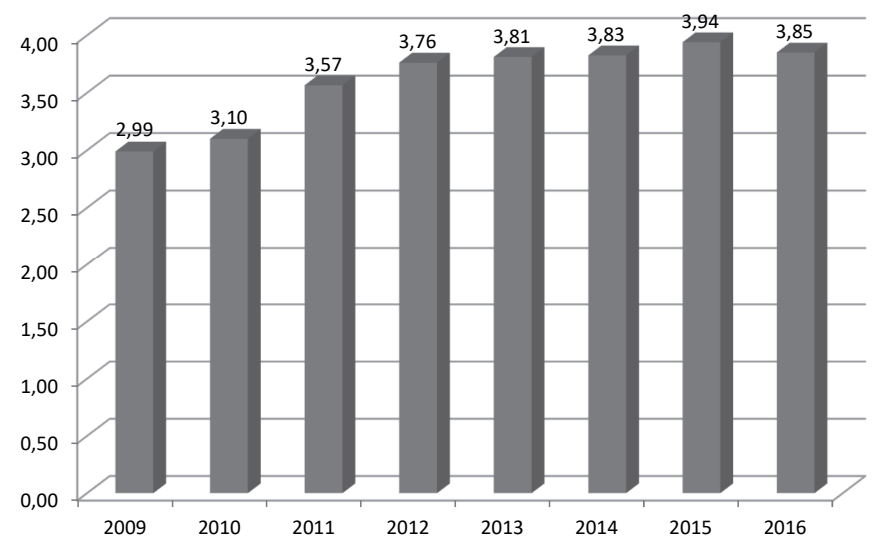

Figure 7. Average costs of 1 vehicle kilometers traveled of mileage in the analyzed enterprises licensed to perform international transport (universal rolling stock with a maximum permissible weight exceeding $12.0 \mathrm{Mg}$, markets of other EU countries, 2009-2016) [PLN/ vehicle kilometers traveled]

Source: own elaboration based on: ITS survey data

Table 2. Weighted average costs 1 vehicle kilometers traveled of the total mileage and according to selected types of costs in 2009-2016 in the analyzed freight transport companies operating the fleet above $12.0 \mathrm{Mg}$ dmc with universal bodies, with a dominant share of transport in relations with markets in other EU countries [PLN/vehicle kilometers traveled]

\begin{tabular}{|l|c|c|c|c|c|c|c|c|}
\cline { 2 - 9 } \multicolumn{1}{l|}{} & 2009 & 2010 & 2011 & 2012 & 2013 & 2014 & 2015 & 2016 \\
\hline $\begin{array}{l}\text { Average costs of 1 vehicle } \\
\text { kilometers traveled } \\
\text { of mileage, including: }\end{array}$ & 2.99 & 3.1 & 3.57 & 3.76 & 3.81 & 3.83 & 3.94 & 3.85 \\
\hline fuels and consumables & 1.13 & 1.24 & 1.46 & 1.48 & 1.53 & 1.52 & 1.47 & 1.51 \\
\hline repair services, repairs, tires & 0.18 & 0.19 & 0.21 & 0.2 & 0.18 & 0.16 & 0.17 & 0.11 \\
\hline $\begin{array}{l}\text { amortization or loss } \\
\text { of market value of rolling } \\
\text { stock }\end{array}$ & 0.19 & 0.18 & 0.14 & 0.16 & 0.17 & 0.15 & 0.15 & 0.13 \\
\hline $\begin{array}{l}\text { other costs of capital } \\
\text { (leasing, credit) }\end{array}$ & 0.33 & 0.28 & 0.15 & 0.17 & 0.1 & 0.08 & 0.07 & 0.05 \\
\hline $\begin{array}{l}\text { remuneration and driver's } \\
\text { delegations as well as social } \\
\text { security for the employer }\end{array}$ & 0.56 & 0.56 & 0.73 & 0.81 & 0.9 & 0.96 & 1.02 & 0.95 \\
\hline $\begin{array}{l}\text { insurance of means } \\
\text { of transport and tax } \\
\text { on means of transport }\end{array}$ & 0.11 & 0.11 & 0.18 & 0.24 & 0.28 & 0.3 & 0.37 & 0.42 \\
\hline road tolls & 0.25 & 0.33 & 0.48 & 0.56 & 0.55 & 0.54 & 0.56 & 0.56 \\
\hline $\begin{array}{l}\text { other costs of the company's } \\
\text { transport activity }\end{array}$ & 0.23 & 0.2 & 0.22 & 0.15 & 0.11 & 0.11 & 0.14 & 0.12 \\
\hline $\begin{array}{l}\text { number of analyzed } \\
\text { companies }\end{array}$ & 63 & 70 & 66 & 48 & 61 & 62 & 61 & 58 \\
\hline
\end{tabular}

Source: ITS database on costs in freight road transport companies 
From the data included in Table 2 among the average costs of 1 vehicle kilometers traveled of mileage in the examined enterprises of international goods transport that mainly operated in relations with markets in other EU countries were dominated by the costs of propelling and operating materials (mainly fuel costs). These costs were, on average, 1.51 PLN/vehicle kilometers traveled in 2016 (around 39.1\% in the average cost of 1 vehicle kilometers traveled of themileage).

However, the average unit costs of drivers' remuneration (including the costs of business trips) and the costs of social insurance for the employer in the surveyed enterprises amounted to PLN 0.95 PLN/ vehicle kilometers traveled in 2016 (24.7\% of the average cost of 1 vehicle kilometers traveled of the mileage in total). The presented calculation results indicate that the average unit costs of drivers' remuneration (including the costs of business trips) and the costs of social insurance for the employer were systematically increasing during the period covered by the research (in 2009, PLN 0.56 PLN/ vehicle kilometers traveled, 18.7\%).

It is clearly seen that in the examined enterprises relatively high and growing from year to year, both nominal and percentage share, the average unit costs of road tolls. In 2016, the cost of road tolls averaged PLN 0.56 PLN/ vehicle kilometers traveled, which represented their share in the average cost of 1 vehicle kilometers traveled of the mileage of $14.6 \%$ (in 2009, 0.25 PLN/vehicle kilometers traveled and $8.5 \%$ respectively).

\section{Conclusions}

The dynamic changes in the share of Polish road transport companies observed in the years 2004-2017 on the international transport market are an important premise for conducting and expanding the scope of research in this area. Analyzes performed on the basis of the results of these studies are helpful in diagnosing the situation and are necessary in political decisions to protect the interests of the Polish side.

ITS is one of the few Polish institutions undertaking attempts to systematically monitor selected segments of the car transport market in Poland, including the production costs of car transport companies. The results of research in the field of costs in road transport, in the face of increasing market competition are interested in state administration entities, which intensively participate in discussions on the issues of transport policy in the EU. Therefore, in this article only selected quantities describing the functioning of Polish road transport in freight transport are indispensable, while they are essential for the work on the EU mobility package.

\section{References}

Bentkowska-Senator K., Kordel Z., Waśkiewicz J., Transport samochodowy ładunków, ITS Publisher, Warsaw 2009.

Kordel Z., Waśkiewicz J., Kamińska E., Pawlak P., Ocena możliwych konsekwencji zmian w europejskich regulacjach dla przewoźników międzynarodowego transportu drogowego rzeczy, part 1, Analiza pozycji polskich przewoźników międzynarodowego transportu rzeczy na rynku europejskim, Topic No. 0618/ZBE/17, Warsaw, 17.08.2017. 
Raczkowski K., Schneider F., Laroche F., Report: The impact of road transport sector regulation on the entrepreneurship and economic growth in the European Union, Motor Transport Institute, Warsaw-Linz-Lyon, February 2017.

Report - Documents issued by GITD - valid in legal transactions, as at December 31, 2015, www.gitd.gov.pl (access: 22.02.2018).

Szymański P., Pakiet mobilności zatrzyma pót Europy, Carrier 2017, 3(54).

Waśkiewicz J., Kordel Z., Balke I., Pawlak P., Badania średnich jednostkowych kosztów w przedsiębiorstwach transportu ciężarowego za okres II pótrocza 2003 r. i I pótrocza 2014 r., ITS Papers No. 6403/ZBE, Warsaw, 30.04.2015.

Waśkiewicz J., Kordel Z., Dorosiewicz S. et al., Projekcja rozwoju rynku międzynarodowego transportu ciężarowego w Polsce do 2030 r. Uwarunkowania, scenariusze i efekty, ITS Papers No. 06/17/ZBE/002 (in progress).

Waśkiewicz J., Kordel Z., Kamińska E., Pawlak P., Badanie stanu i kierunków zmian na rynku transportu samochodowego w Polsce, part 2, Badanie kosztów i stawek przewozowych w przedsiębiorstwach międzynarodowego transportu ciężarowego w 2016 r. i analiza zmian w okresie 2009-2016, ITS Papers No. 6600/2/ZBE, Warsaw, 30.06.2017.

\section{Corresponding authors}

Zdzisław Kordel can be contacted at: zdzislawkordel@wp.pl Jerzy Waśkiewicz can be contacted at: jerzy.waskiewicz@its.waw.pl 